\title{
EquiLIBRIUM
}

Quarterly Journal of Economics and Economic Policy

2015 VOLUME 10 ISSUE 1, March

p-ISSN 1689-765X, e-ISSN 2353-3293

www.economic-policy.pl

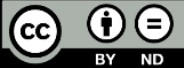

Richert-Kaźmierska, A. (2015). Demographic Changes in Poland - The Regional Dimension. Equilibrium. Quarterly Journal of Economics and Economic Policy, 10(1), pp. 113-128, DOI: http://dx.doi.org/10.1 2775/EQUIL.2015.006

Anita Richert-Kaźmierska*

Gdansk University of Technology, Poland

\section{Demographic Changes in Poland - The Regional Dimension}

JEL Classification: $J 11 ; J 14 ; R 11$

Keywords: demographic changes; population ageing; regional diversity of ageing

\begin{abstract}
The progressive ageing process concerns both Poland and other Member States of the European Union. In recent years, the share of workers of nonmobile and post-productive age in the total population has been rising, and according to forecasts, in 2035 people aged 45 years and over will represent twothirds of our society. Since the year 2012, announced the Year of Active Ageing and Solidarity between Generations by the European Commission, more and more attention has been paid in the Polish public space to the issues of an ageing society, including its impact on the health of the economy.

The article notes that the ageing process does not occur uniformly across all Polish regions, i.e. at the same pace and with the same intensity. The results of studies indicating the regions being most vulnerable to the ageing of the regional community and the negative consequences of this process in the next two decades are presented.
\end{abstract}

(C) Copyright Institute of Economic Research \& Polish Economic Society Branch in Toruń

Date of submission: December 19, 2014; date of acceptance: February 5, 2015

* Contact: anita.richert@zie.pg.gda.pl, Faculty of Management and Economics, Gdansk University of Technology, ul. Gabriela Narutowicza 11/12, 80-233 Gdańsk, Poland 


\section{Anita Richert-Kaźmierska}

\section{Introduction}

The ageing of society is a global phenomenon (Lee, 1994, pp. 8-49), although its pace is different in different parts of the world, countries and regions (Population Division of the United Nations, 2013; Heran, 2013, pp. 13-20; Żołędowski, 2012, p. 30). The society is ageing (Stańczak, 2014) if the share of seniors in the total population is rising ${ }^{1}$. According to Rosset (1959), the population reaches the so-called demographic senility when the population aged 60 years or more comprises at least $12 \%$ of the total population. The measures of an ageing population may also be the fertility rate below the generation replacement rate, decreasing mortality among the elderly, increasing median age of the population (Suntoo, 2012), as well as increasing life expectancy and life in good health expectancy (Burzyńska, et al., 2010, pp. 530-536).

The ageing of the population is affected by many factors. Among the basic ones, the literature mentions: the decreasing number of births and fertility rates and increasing life expectancy (Gavrilov \& Heuveline, 2003; Richert-Kaźmierska 2013, p. 127). In addition, the rate of ageing of communities in various regions is affected by migration (Strzelecki \& Witkowski, 1991, pp. 59-72), including economic emigration (Devictor, 2012).

The demographic crisis, linked to the ageing of the society, currently relates primarily to industrialized, well-developed countries (Population Division of the United Nations, 2013). According to Batini, Callen and McKibben (2006), the developing countries will be using the so-called demographic dividend in the next 20-30 years (Bloom, et al., 2001, p. 3). Only in the following decades also this group of countries will experience the ageing of population and the demographic changes will affect their macroeconomic situation, including the level of savings, investment, capital flows and changes in the level of productivity. The World Health Organization (WHO) predicts that the ageing process in these countries will progress much faster than before in the industrialized ones. The published estimates show that, while the increase in the proportion of people aged 65 years and older from $7 \%$ to $14 \%$ of the total population in France took over 100 years, in Brazil it will take place in just 20 years (National Institute of Aging, National Institute of Health, World Health Organization, 2011).

\footnotetext{
${ }^{1}$ The Polish Central Statistical Office considers the threshold of old age, i.e. the age beyond which a person belongs to seniors, to be 60 or 65 years (uniformly for men and women or the age of 65 years for men and 60 years for women). The UN studies use uniform age for males and females -65 years.
} 
The ageing of society is a complex process, affecting i.e. the condition and the stability of the public finance sphere, pension schemes or the organization of health and welfare. Moreover, it shapes a new reality in the labor market, as well as affects the supply and demand in the market for goods, services and capital (Cutler, et al., 1990; Kotowska, 2006, pp. 55-89; Prskawetz, et al., 2008, pp. 298-323). An ageing society also means social change, including the family structure and intra-family relationships, education system and the organization of cultural and social life of the elderly (Li, et al., 2007).

The analyses related to demographic changes and their consequences are frequently carried out in macroeconomic perspective (Arnott \& Chaves, 2012; Clement, 2008). However, the intensity and nature of the effects of ageing are varied regionally (Department of Economic and Social Affairs, United Nations, 2008; Styczyńska \& Zaman, 2013). It is primarily the local and regional authorities who are facing new challenges due to the growing share of older people in local and regional communities (Gromig \& Trapp, 2006; Ferry \& Baker, 2006). One of the key priorities in the decisions and actions taken by them is meeting the needs of the elderly. Błędowski (2002, p. 175) writes about the need to create a social policy towards the elderly as a system of activities aimed at people of retirement age and their families. Such actions would be aimed at comprehensive compensation of the capabilities to meet one's own needs, which decrease with age, as well as at the integration with the local community. At the same time, the subject-matter literature emphasizes the need for the development of local and regional comprehensive policies towards ageing, understood more widely than policy aimed exclusively at supporting the elderly (Ilmarinen, 2005, p. 41; Cruz-Saco \& Zelenev, 2010; Warner, et al., 2010; Błędowski 2002 p. 110; DTT Global Office Creative Studio, 2007).

This article attempts at moving away from the analysis of issues related to ageing in a national perspective, and transferring it to the level of regions. It is shown that the demographic changes in Polish regions have an uneven pace, which means that in each of them the consequences of population ageing may be felt differently. The main objective of the study conducted by the author was to identify the regions with the lowest and the highest rate of ageing of the regional community, as well as the regions for which the population data forecasts for the year 2035 are the most inferior due to the age structure of their population. The identification of the existing and projected demographic disparities between regions would serve as an inspiration for a debate on the need to create a policy on ageing at regional level, according to the principle of differentiation of the instruments used in it. 


\section{Methodology of the Research}

The changes in the size and age structure of the Polish population observed in the past and projected for the next decade show considerable territorial variation. Therefore, the main objective of the study was to answer the following questions:

- whether there are similarities in the age structure of the population in each of the regions (at present and in the future),

- in which regions the pace of population ageing is highest and where the lowest,

- in which regions the demographic situation is unfavorable economically in the perspective of the next two decades, i.e. where the people of retirement age will constitute the greatest burden on regional communities.

The study consisted of conducting basic and multivariate statistical analysis.

The diagnosis of similarities in age structures of individual provinces was conducted using the multi-dimensional analysis of agglomerates. In order to group the selected provinces, the method of agglomeration with full binding and square Euclidean distance was chosen.

The pace of population ageing was established on the basis of the calculation of the average yearly changes in the age groups and the changes of shares of each of the groups in the total population in the year 2035, compared to the year 2014. In addition, the demographic burden factor ${ }^{2}$, including the demographic burden related to senior citizens ${ }^{3}$, was calculated for all provinces for the years 2014 and 2035.

To carry out the above-mentioned analyses, the data from the population forecasts for the years 2008-2035 prepared by the Central Statistical Office (CSO) was used. The population projections for the period 2014-2035 were downloaded from the CSO database, broken down by age and province. The data for the individual provinces were divided into five age groups (017 years, 18-44 years, 45-64 years, 65-79 years and 80 years and more). The adopted distribution allowed for an assessment of the demographic changes in the breakdown meaningful in view of the functioning of local

\footnotetext{
${ }^{2}$ In this case, the demographic burden factor was calculated as the ratio of the number of people at an age when they are economically inactive or passive, i.e. of non-productive age (the number of children aged 0-17 years plus the number of people aged 65 years or more) to the number of people of working age (number of persons aged 18-64 years).

${ }^{3}$ The demographic burden factor related to the elderly was in this case calculated as the ratio of the number of persons aged 65 years and more to the number of individuals of working age (number of persons aged 18-64 years).
} 
and regional economies, i.e. into the group of individuals of pre-productive age (0-17 years), the so-called prime age $e^{4}(18-44$ years), the non-mobile productive age (45-64 years) and retirement age (65 years or more), with distinction of the age group of the aged 80 years or more.

The results obtained from such study led to the formulation of proposals related to the present and future demographic situation of Polish regions and the potential economic and social consequences which in relation to such circumstances will have to be faced by the local and regional authorities.

\section{The Specificity and the Pace of Demographic Changes in the Regions of Poland}

Poland has exceeded the threshold of the demographic old age ${ }^{5}$ in 1967 (Główny Urząd Statystyczny, 1968). In the period 1994-2002 the share of the population aged 65 and over in the general population increased from $11 \%$ to $12.6 \%$, and aged 60 and more from $15.7 \%$ to $16.8 \%$ (Rządowa Rada Ludnościowa, 2003). According to data from the Central Statistical Office (CSO) in Poland, the population aged 65 and more in 2014 constitutes $15.3 \%$ and in the year 2035 it will constitute $24.5 \%$ of the total population (Główny Urząd Statystyczny, 2014) (see Table 1).

Table 1. The age structure of the Polish population in the years 2014 and 2035

\begin{tabular}{|l|c|c|}
\hline \multirow{2}{*}{ Age groups } & $\mathbf{2 0 1 4}$ & $\mathbf{2 0 3 5}$ \\
\cline { 2 - 3 } & [\% of total population] \\
\hline $0-17$ years & 18.2 & 15.3 \\
\hline $18-44$ years & 39.8 & 29.4 \\
\hline $45-59 / 64^{*}$ & 23.6 & 27.4 \\
\hline $60+/ 65+^{* *}$ & 18.4 & 28.0 \\
\hline
\end{tabular}

* 59 years for women / 64 years for men

** 60 years and more for women and 65 years and more for men

Source: Główny Urząd Statystyczny (2014).

${ }^{4}$ The prime age term is not explicitly defined in the subject-matter literature, however it is referred to i.a. by Kautonen (2008) and Boushey (2005, pp. 659-670).

5 According to the UN standards, it represents a 7-percent share of persons aged 65 years and over in the general structure of the population. 
According to the predictions of CSO, the population of Poland in the period from 2014 until the year 2035 will decrease by more than 2 million and will amount to 35993 thousand in the year 2035. During the same period, the median age will rise by about seven years and in the year 2035 will be 47.9. The demographic changes will not, however, take place evenly on a national scale. The current and future demographic situation shows considerable variation in individual regions (see Table 2).

Table 2. The age structure of the population in the provinces of Poland in the years 2014 and 2035

\begin{tabular}{|c|c|c|c|c|c|c|c|c|c|c|}
\hline \multirow{4}{*}{ Provinces } & \multicolumn{10}{|c|}{ Age groups } \\
\hline & \multicolumn{2}{|c|}{ 0-17 } & \multicolumn{2}{|c|}{$18-44$} & \multicolumn{2}{|c|}{$45-64$} & \multicolumn{2}{|c|}{$65-79$} & \multicolumn{2}{|c|}{$\begin{array}{c}80 \text { years } \\
\text { and more }\end{array}$} \\
\hline & $\underset{ঠ}{\stackrel{ঠ}{ঠ}}$ & ڤి & $\underset{ণ}{\stackrel{ \pm}{ٍ}}$ & ๙ి &  & 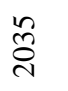 & $\underset{\text { ¿ }}{\stackrel{\Xi}{\sim}}$ & $\tilde{\overbrace{}}$ & $\stackrel{ \pm}{\stackrel{\Delta}{d}}$ & $\stackrel{n}{\tilde{c}}$ \\
\hline & \multicolumn{10}{|c|}{ [\% of total population] } \\
\hline dolnośląskie & 16.9 & 14.7 & 39.6 & 29.5 & 28.1 & 31.9 & 11.4 & 16.1 & 3.9 & 7.7 \\
\hline $\begin{array}{l}\text { kujawsko- } \\
\text { pomorskie }\end{array}$ & 18.8 & 15.9 & 39.8 & 30.3 & 27.0 & 30.7 & 11.0 & 15.9 & 3.5 & 7.1 \\
\hline lubelskie & 18.6 & 15.5 & 39.0 & 29.5 & 26.6 & 30.6 & 11.5 & 16.9 & 4.2 & 7.5 \\
\hline lubuskie & 18.7 & 15.9 & 40.0 & 30.1 & 27.5 & 31.0 & 10.5 & 16.0 & 3.3 & 7.1 \\
\hline łódzkie & 16.9 & 14.7 & 38.2 & 28.8 & 30.0 & 31.5 & 12.5 & 17.1 & 4.4 & 8.0 \\
\hline małopolskie & 18.9 & 16.2 & 40.8 & 31.1 & 25.6 & 30.6 & 10.9 & 15.6 & 3.8 & 6.5 \\
\hline mazowieckie & 18.4 & 16.2 & 39.8 & 30.6 & 26.2 & 31.1 & 11.3 & 15.0 & 4.3 & 7.1 \\
\hline opolskie & 16.2 & 13.7 & 39.7 & 29.0 & 28.5 & 32.0 & 11.8 & 17.9 & 3.9 & 7.3 \\
\hline podkarpackie & 19.0 & 16.0 & 40.7 & 30.2 & 26.0 & 30.9 & 10.6 & 16.4 & 3.8 & 6.6 \\
\hline podlaskie & 18.0 & 15.4 & 39.5 & 29.1 & 26.8 & 30.6 & 11.2 & 17.5 & 4.5 & 7.3 \\
\hline pomorskie & 19.8 & 17.0 & 40.2 & 31.4 & 26.1 & 30.1 & 10.6 & 14.8 & 3.4 & 6.8 \\
\hline śląskie & 16.8 & 14.7 & 39.0 & 29.2 & 28.3 & 31.5 & 12.3 & 17.1 & 4.5 & 7.6 \\
\hline $\begin{array}{l}\text { świętokrzys- } \\
\text { kie }\end{array}$ & 17.3 & 14.3 & 38.3 & 28.1 & 27.8 & 31.4 & 12.1 & 17.1 & 4.5 & 7.6 \\
\hline $\begin{array}{l}\text { warmińsko- } \\
\text { mazurskie }\end{array}$ & 19.5 & 16.3 & 40.0 & 30.6 & 27.2 & 30.2 & 10.0 & 16.1 & 3.4 & 6.8 \\
\hline wielkopolskie & 19.3 & 16.4 & 40.8 & 31.1 & 26.0 & 31.0 & 10.6 & 15.1 & 3.3 & 6.5 \\
\hline $\begin{array}{l}\text { zachodniopo- } \\
\text { morskie }\end{array}$ & 17.9 & 15.3 & 39.7 & 30.1 & 28.0 & 31.3 & 10.9 & 16.0 & 3.5 & 7.3 \\
\hline
\end{tabular}

Source: own calculations based on Główny Urząd Statystyczny (2009).

According to the population projections for the years 2008-2035, in 2014 the regions with the highest share of persons of pre-productive age (0-17 years) in the total population were the pomorskie (19.8\%), warmińsko-mazurskie $(19.5 \%)$ and wielkopolskie $(19.3 \%)$ provinces. The highest 
share of people of working age (18-64 years) in the total population was recorded in the opolskie (68.2\%), zachodniopomorskie $(67,7 \%)$ and dolnośląskie $(67,7 \%)$ provinces. It has to be noted, however, that the highest share of persons of prime age in total population was reported in the wielkopolskie $(40.8 \%)$, małopolskie $(40.8 \%)$, podkarpackie $(40.7 \%)$ and pomorskie $(40.2 \%)$ provinces, while the share of people of the non-mobile productive age was the highest in the opolskie (28.5\%), śląskie $(28.3 \%)$ and dolnośląskie $(28.1 \%)$ provinces. The provinces with the highest share of people aged over 65 years in the general population are łódzkie (16.9\%) and świętokrzyskie (16.6\%). According to the same data, in the year 2035 the provinces with the highest share of persons of pre-productive age in the general population will be pomorskie $(17.0 \%)$, wielkopolskie $(16.4 \%)$ and warmińsko-mazurskie (16.3\%). On the other hand, the provinces with the highest share of post-productive age are opolskie (25.2\%) and łódzkie (25.1\%). The share of people of prime age in the total population will be largest in pomorskie $(31.4 \%)$, wielkopolskie $(31.1 \%)$ and małopolskie $(31.1 \%)$ provinces.

On the basis of the data collected it can be concluded that in 2014 the most favorable demographic situation was present in pomorskie and wielkopolskie provinces. In both these provinces a relatively high proportion of people of pre-productive age and prime age, as well as a relatively low share of people of post-productive age (65 years and over) in the total population have been reported at the same time. On the other hand, the opolskie and dolnośląskie provinces, despite having the highest share of people of productive age in the general population, should be considered to be demographically threatened. A significant part of the 18-64 age group are, in fact, people of non-mobile working age, who in subsequent years will be shifting towards the "outbound from the labor market" group and joining the already large group of people of post-productive age. An additional threat in the case of both these provinces is the lowest share of people of pre-productive age in the overall population. The highest share of people of post-productive age in the overall population, including the group of people of old age, has been reported for the łódzkie and świętokrzyskie provinces. It seems that these two provinces were first to begin to feel the effects of an ageing population in Poland.

The verification of the similarity of the structures of the provinces population in 2014 has been conducted basing on the multi-dimensional analysis of agglomerates. The tree diagram (see Fig. 1) confirms the above indicated differentiation and allows for dividing the provinces into two main groups: having an adverse demographic structure (dolnośląskie, opolskie, śląskie, świętokrzyskie, łódzkie) and having a moderately favorable demographic 
structure, with two regions being most favorable as far as demographics is concerned (pomorskie and wielkopolskie).

According to the forecasts of the Central Statistical Office, the most significant demographic changes in the years 2014-2035 will take place in the opolskie, podkarpackie, podlaskie and warmińsko-mazurskie provinces. And so, in the opolskie province within the next 21 years the share of people aged 18-44 years in the total population will decrease by 10.6 percentage points (p.p.), while the proportion of persons aged 65 years and over will increase by 9.6 p.p. In the warmińsko-mazurskie province the largest decrease of the population of pre-productive age will be observed (by 3.2 p.p.), together with the increase in the number of persons aged 65 and over by more than 9.5 p.p. In the podkarpackie and podlaskie provinces, the share of the persons of prime age in the total population will decrease by over 10 p.p., and in addition, a significant decrease in the share of individuals of pre-productive age will occur (by more than 3 percentage points).

Figure 1. The similarity of population age structures of the provinces in Poland in the year 2014 - a tree diagram

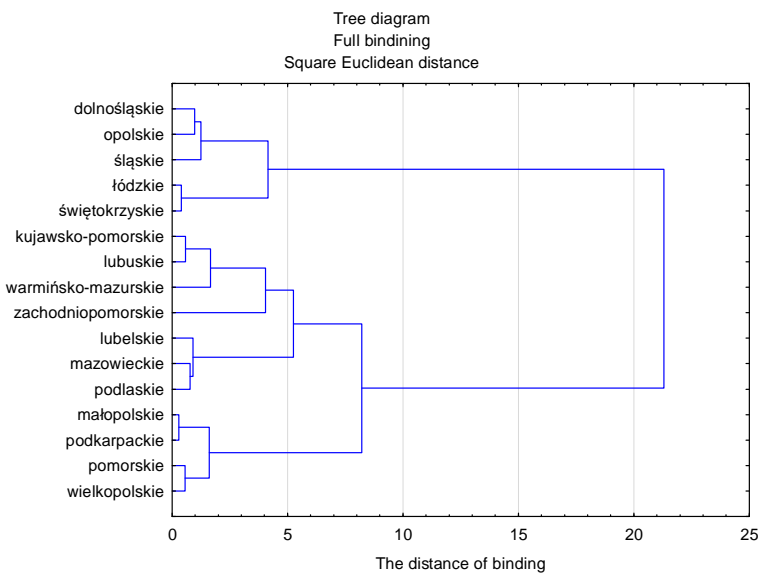

Source: own calculations based on Główny Urząd Statystyczny (2009).

The provinces in which the demographic situation will change relatively least, are pomorskie and mazowieckie. In the mazowieckie province, a decrease in the share of individuals of pre-productive age by 2.2 p.p. and the individuals of prime age by 9.1 p.p., as well an increase in the proportion of people of old age by 2.8 p.p. will occur. In turn, in the pomorskie province the lowest decrease in the share of individuals of prime age (by 
8.8 p.p.) and relatively insignificant decrease of the share of people of preproductive age (by 2.8 p.p.) are projected.

In the years 2014-2035 the largest average yearly changes are projected:

- in the 0-17 age group: in the świętokrzyskie province (-0.89\%),

- in the 18-44 age group: in the opolskie province (-1.5\%),

- in the 45-64 age group: in the małopolskie province (+0.9\%),

- in the 65-79 age group: in the warmińsko-mazurskie province $(+2.3 \%)$,

- in the $80+$ age group: in the lubuskie province $(+3.7 \%)$.

Figure 2. Average yearly changes in the proportion of the 18-44 (A) and 65-79 (B) age groups in the total population of the provinces in the years 2014-2035

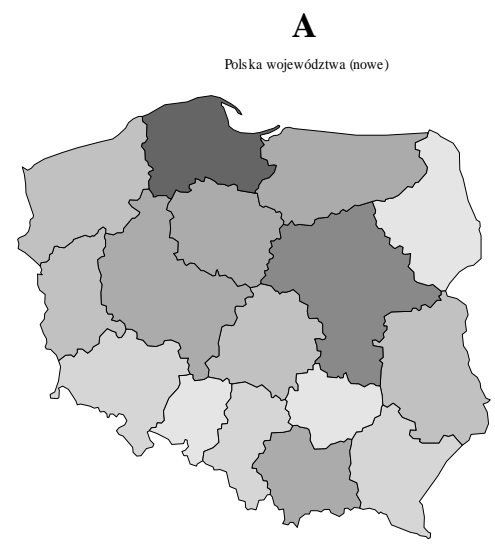

B

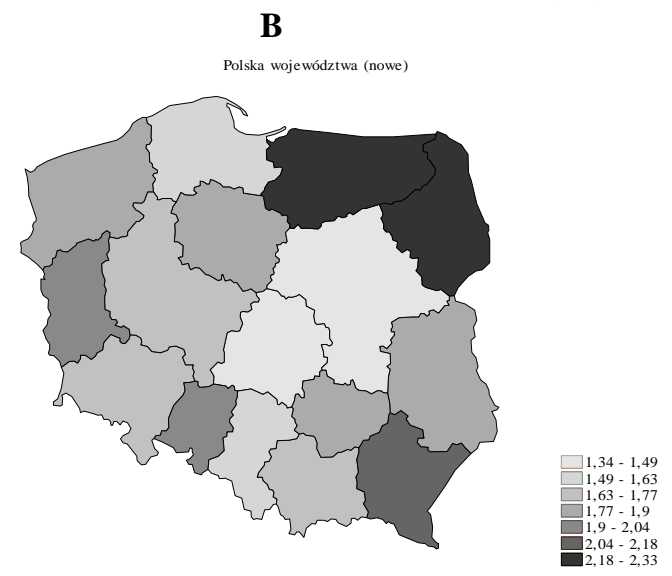

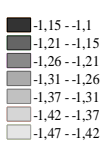

$-1,47--1,42$

Source: own calculations based on Główny Urząd Statystyczny (2009). 


\section{2}

As demonstrated in Figure 2, in years 2014-2035 the greatest rate of adverse changes consisting in reducing the share in of the 18-44 age group in the population of the region will be present in the opolskie, świętokrzyskie and podlaskie provinces. On the other hand, the changes consisting of a rapid increase in the share of the 65-79 age group in the general population will be present in the warmińsko-mazurskie, podlaskie, podkarpackie, opolskie and lubuskie provinces.

The verification of the similarity of the structures of the provinces population in 2035 has been conducted basing on the multi-dimensional analysis of agglomerates. The tree diagram (see Fig. 3) confirms that the specificity and pace of the demographic changes projected for the years 2014-2035 will affect the new layout of the demographic similarities among provinces. Once can still talk about the two major groups of provinces being similar to each other in terms of the age structure of the population of the region, although in comparison to the figures for the year 2014 it is more possible to extract four subgroups of provinces similar in terms of their age structure. Among the similar provinces, the most beneficial age structure predicted for the year 2035 should be present in pomorskie, mazowieckie, wielkopolskie and małopolskie.

Figure 3. The similarity of population age structures of the provinces in Poland in the year 2035 - a tree diagram

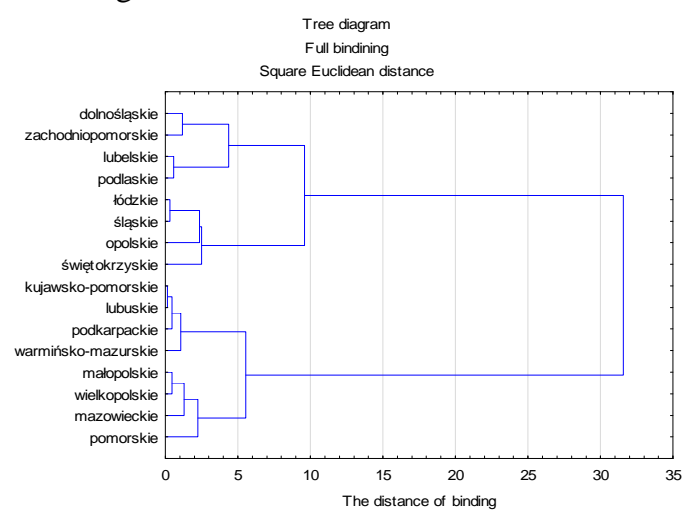

Source: own calculations based on Główny Urząd Statystyczny (2009).

The ageing of society resulting from an increase in the share of the individuals of old age in the decreasing population means a number of negative consequences for the economy. The demographic burden rate and demographic burden rate related to seniors are considered to be measure of the intensity of a given population's ageing. 
In the year 2014, the average demographic burden factor calculated as the ratio of the number of people of an age when they are economically inactive or passive, i.e. of non-productive age (the number of children aged 0-17 years plus the number of people aged 65 years or more) to the number of people of working age (number of persons aged 18-64 years), amounted to 0.49 for all the regions, however in the year 2035 it will amount to as much as 0.64 . In turn, the demographic burden factor related to seniors, calculated as the ratio of the number of persons aged 65 and more to the number of persons of working age (the number of persons aged 18-64 years), in the year 2014 averaged 0.22 for all regions, while in the year 2035 it will amount to as much as 0.39 (see Table 3).

Table 3. The demographic burden factor and the demographic burden factor related to seniors in the Polish regions in the years 2014 and 2035

\begin{tabular}{|l|c|c|c|c|}
\hline \multirow{2}{*}{\multicolumn{1}{c|}{ Regions }} & \multicolumn{2}{c|}{$\begin{array}{c}\text { The demographic } \\
\text { burden factor }\end{array}$} & \multicolumn{2}{c|}{$\begin{array}{c}\text { The demographic } \\
\text { burden factor related } \\
\text { to seniors }\end{array}$} \\
\cline { 2 - 5 } & $\mathbf{2 0 1 4}$ & $\mathbf{2 0 3 5}$ & $\mathbf{2 0 1 4}$ & $\mathbf{2 0 3 5}$ \\
\hline dolnośląskie & 0.48 & 0.63 & 0.23 & 0.39 \\
\hline kujawsko-pomorskie & 0.49 & 0.64 & 0.22 & 0.38 \\
\hline lubelskie & 0.52 & 0.67 & 0.24 & 0.41 \\
\hline lubuskie & 0.48 & 0.64 & 0.20 & 0.38 \\
\hline łódzkie & 0.51 & 0.66 & 0.25 & 0.42 \\
\hline małopolskie & 0.50 & 0.62 & 0.22 & 0.36 \\
\hline mazowieckie & 0.52 & 0.62 & 0.24 & 0.36 \\
\hline opolskie & 0.47 & 0.64 & 0.23 & 0.41 \\
\hline podkarpackie & 0.50 & 0.64 & 0.21 & 0.38 \\
\hline podlaskie & 0.51 & 0.67 & 0.24 & 0.42 \\
\hline pomorskie & 0.51 & 0.63 & 0.21 & 0.35 \\
\hline śląskie & 0.49 & 0.63 & 0.24 & 0.41 \\
\hline świętokrzyskie & 0.51 & 0.68 & 0.25 & 0.44 \\
\hline warmińsko-mazurskie & 0.49 & 0.65 & 0.20 & 0.38 \\
\hline wielkopolskie & 0.49 & 0.61 & 0.21 & 0.35 \\
\hline zachodniopomorskie & 0.48 & 0.63 & 0.21 & 0.38 \\
\hline
\end{tabular}

Source: own calculations based on Główny Urząd Statystyczny (2009). 
In all regions the demographic burden factors and demographic burden factors related to seniors in the year 2035 will be higher than in the year 2014. In the case of the demographic burden factor related to seniors, expressly indicating the progress of the ageing of the population, the most unfavourable results are projected for the świętokrzyskie, podlaskie, łódzkie, śląskie, opolskie and lubelskie provinces. In turn, the largest increase in the demographic burden factor related to seniors in the period 2014-2035 is projected to take place in the świętokrzyskie, warmińskomazurskie, podlaskie, opolskie and lubuskie provinces.

\section{Conclusions}

The results of analyses of the population data presented in the article confirmed that the demographic changes, including the ageing of the society over the next two decades, will concern all Polish provinces. The projected pace and scope of these changes will, however, differ among the provinces.

The provinces in which the rate of adverse changes is expected to be the highest include warmińsko-mazurskie, podlaskie, podkarpackie, opolskie and lubuskie. The greatest changes in the share of young people (0-17 years) in the total population in the years 2014-2035 are projected for the provinces: świętokrzyskie $(-0.89 \%)$ lubelskie $(-0.86 \%)$ and warmińskomazurskie $(-0.85 \%)$. In the 65-79 age group, the greatest changes are, in turn, projected in the warmińsko-mazurskie $(+2.32 \%)$, podlaskie $(+2.18 \%)$ and podkarpackie $(+2.11 \%)$ provinces. The świętokrzyskie, podlaskie, łódzkie, śląskie, opolskie and lubelskie provinces also have the least favourable demographic forecasts for the year 2035. In these provinces, the share of the population of pre-productive age and prime age in the overall population will decrease significantly over the next two decades, whereas the share of older people (65 years and over) and the demographic burden factor related to seniors will increase.

The application of the method of multi-dimensional analysis of agglomerates allowed for distinguishing groups of provinces demographically similar to each other in the years 2014 and 2035. In both cases, two main groups of similar provinces were extracted. A subgroup of provinces with relatively best demographic situation in the years 2014 and 2035 was also discerned. In 2014, the group is made up by the pomorskie and wielkopolskie provinces. In the year 2035, it will comprise the pomorskie, mazowieckie, wielkopolskie and małopolskie provinces. 
The changing demographic situation in individual provinces forces the regional authorities to take appropriate actions aimed at limiting the negative effects of the ageing of the population and adapting the regional policies to new conditions. However, as the pace and scope of the projected changes are varied, the activities of the regional government must be selected according to the current and future demographic situation in the regions.

The article does not provide any research results allowing for the formulation of clear conclusions on the impact of demographic changes on the economic condition of each of the provinces over the next two decades. However, based on the conclusions of the research referred to in the first part of the article, it can be assumed that the most vulnerable are the economies of the regions with the least favorable demographic forecasts. The growing share of persons in their retirement age means for the regional economies shrinking real labor resources and declining economic activity (Kryńska \& Kwiatkowski, 2013, pp. 87-90). In addition, the unfavorable demographic situation forces the increase in local and regional governments' expenses for social policy issues (Błędowski, 2002, pp. 197-236), including medical and social care addressed to the oldest inhabitants (Bien, 2012, pp. 151-158) . Implementation of appropriate regulations and actions is also needed in terms of elderly's stationary and home care system (Parlament Europejski, 2010). A growing number of people aged over 80 who will require permanent care (Najwyższa Izba Kontroli, 2015, pp. 6-7) may determine the withdraw of persons in their non-mobile productive age from the labor market. This group will be expected to provide the care for their parents or other elderly relatives (sandwich generation) (Taylor, et al., 2013). Such a process would make the size and structure of regional labor supply even worse.

Taking the arguments above into consideration, in view of the ageing of the regional communities, the most urgent and intensive actions related to the adaptation of the regional economy, including the infrastructure, labor market organization, social policy etc., should be taken by the governments of the świętokrzyskie, podlaskie, łódzkie, śląskie, opolskie and lubelskie provinces. In turn, the pomorskie, mazowieckie, małopolskie and wielkopolskie provinces (regions with relatively the most favorable demographic forecasts for the year 2035) should focus on activities aimed at ensuring the maintenance of a favorable demographic structure and exploiting the potential inherent in "young" regional communities.

Each of the provinces should work out its own policy in relation to the ageing of the regional community, corresponding to its current and future demographic situation. Without such a policy or in the case of the imple- 
mentation of a model that fails to match the characteristics of the region, the condition of the regional economy can be threatened and the quality of life in the region, as well as its competitiveness can decrease.

\section{References}

Arnott, R., \& Chaves, D. (2012). Demograohic changes, financial markets and economy. Financial Analysts Journal, 68(1). http://dx.doi.org/10.2469/faj. v68.n1.4.

Batini, N., Callen, T., \& McKibbin, W. (2006). The Global Impact on Demographic Change. IMF Working Paper WP/06/9. International Monetary Fund.

Bień, B. (2012). Opieka geriatryczna w perspektywie starzenia się ludności Polski. In: J. Hrynkiewicz (Ed), O sytuacji ludzi starych. Warszawa: Rządowa Rada Ludności.

Bloom, D., Canning D., \& Sevilla J. (2001). Economic growth and the demographic transition. Working Paper 8685, Cambridge, National Bureau of Economic Research.

Błędowski, P. (2002). Lokalna polityka społeczna wobec ludzi starych. Warszawa: SGH.

Boushey, H. (2005). No Way Out: How Prime-Age Workers Get Trapped in Minimum-Wage Jobs, Working USA. Journal of Labor and Society, 8.

Burzyńska, M., Marcinkowski, J., Bryła, M., \& Maniecka-Bryła, I. (2010). Life Expectancy i Healthy Life Years jako podstawowe miary oceny sytuacji zdrowotnej ludności. Problemy Higieny i Epidemiologii, 91(4).

Clement, W. (2008). The implication of demographic change. Working papers, Zurich, Zurich Government and Industry Affairs.

Cutler, D., Potreba, J., Sheiner, L., \& Summers, L. (1990). An ageing society: opportunity or challenge?. Brookings Papers on Economic Activity, 1.

Department of Economic and Social Affairs, United Nations. (2008). Regional Dimensions of the Ageing Situation. New York.

Devictor, X. (2012). Starzenie sie spoteczeństwa a gospodarka. The World Bank, Retrieved form http://www.worldbank.org/pl/news/opinion/2012 /06/14/poland-aging-and-the-economy (03.12.2014).

DTT Global Office Creative Studio. (2007). The Graying Government Workforce. New York. Retrieved form http://www.deloitte.com /assets/DcomShared\%20Assets/Documents/dtt_publicsector_snapshot _greygovt_113007.pdf

Ferry, M., \& Baker, R. (2006). Regional strategies and demographic ageing. Age Proofing Toolkid. Brussel: Regions for All Ages.

Gavrilov, L., \& Heuveline, P. (2003). Ageing of Population. In: P. Demeny, \& G. McNicoll (Eds), The Encyclopedia of Population. New York: Macmillan Reference.

Główny Urząd Statystyczny. (1968). Rocznik Demograficzny 1945-1966. Warszawa. 
Główny Urząd Statystyczny. (2009). Prognoza ludności na lata 2008-2035. Warszawa.

Główny Urząd Statystyczny. (2014). Prognoza ludności na lata 2014-2050. Warszawa.

Gromig, B., \& Trapp J. (2006). The impact of demographic change on local and regional government. Brussel: German Institute of Urban Affairs.

Heran, F. (2013). The Population Ageing Process in Global Perspective. In S. McDaniel, \& Z. Zimmer (Eds), Global Ageing in the Twenty-First Century. Challenges, Opportunities and Implications. Ashgate.

Ilmarinen, J. (2005). Towards a longer worklife. Ageing and the quality of worklife in the European Union. Helsinki: Finish Institute of Occupational Health.

Kautonen, T. (2008). Understanding the older entrepreneur: Comparing Third Age and Prime Age entrepreneurs in Finland. Journal of Business Science and Applied Management, 3(3).

Kotowska, I. E. (2006). Older workers in the labour market and retirement policies. In R. Palomba, \& I. E. Kotowska (Eds), The economically active population in Europe. "Population Studies", No 40, Strasbourg: Council of Europe Publishing.

Kryńska, E., \& Kwiatkowski, E. (2013). Podstawy wiedzy o rynku pracy. Łódź: Wydawnictwo Uniwersytetu Łódzkiego.

Lee, R. D. (1994). The formal demography of population aging, transfers, and the economic life cycle. In L. G. Martin, \& S. H. Preston (Eds), Demography of Ageing. Washington D.C.: National Academy Press.

Li, R., Ladarola, A., \& Maisano, Ch. (2007). Why population aging matters. A global perspective. New York, National Institute of Aging, US Department of Health and Human Services.

Najwyższa Izba Kontroli. (2015). Opieka medyczna nad osobami w wieku podeszłym. Informacja o wynikach kontroli. Warszawa.

National Institute of Aging, National Institute of Health, World Health Organization. (2011). Global Health and Aging. New York. Retrieved form http://www.nia.nih.gov/sites/default/files/global_health_and_aging.pdf

Parlament Europejski. (2010). Dtugookresowa opieka nad osobami w podeszłym wieku. Rezolucja Parlamentu Europejskiego z dnia 9 września 2010r. P7_TA(2010)0313.

Population Division of the United Nations. (2013). World Population Prospects. The 2012 Revision. New York, Department of Economic and Social Affairs of the United Nations Secretariat.

Prskawetz, A., Fent, T., \& Guest, R. (2008). Workforce ageing and labor productivity: the role of supply and demand for labor in the G7 countries. In A. Prskawetz, D.E. Bloom, \& W. Lutz (Eds), Population Aging, Human Capital Accumulation and Productivity Growth. New York: Population Council.

Richert-Kaźmierska, A. (2013). Is There any Demand For the Workers Aged 50+ in Poland?. Equilibrium. Quarterly Journal of Economics and Economic Policy, 8(3). http://dx.doi.org/10.12775/EQUIL.2013.023.

Rosset, E. (1959). Proces starzenia się ludności. Studium demograficzne. Warszawa: Polskie Wydawnictwa Gospodarcze. 
Rosset, E. (1971). Człowiek stary a społeczeństwo. Studia Demograficzne, 25.

Rządowa Rada Ludnościowa. (2004). Sytuacja demograficzna Polski. Raport 2003. Warszawa.

Stańczak, J. (2014). A term used in the statistical research of the public data. Główny Urząd Statystyczny, Retrieved form http://old.stat.gov.pl /gus/definicje_PLK_HTML.htm?id=POJ-1718.htm (03.12.2014).

Strzelecki, Z., \& Witkowski, J., (1991), Migration and population aging: a case of Poland. Polish Population Review, 1.

Styczyńska, I., \& Zaman, C. (2013). Regional disparities, ageing and territorial aspects of employment. Neujobspolicy Brief, 8(6).

Suntoo, R. (2012). Population Ageing and the Theory of Demographic Transition: The Case of Mauritius. University of Mauritius Research Journal, 18.

Taylor, P., Parker, K., Patten E., \& Motel S. (2013). The Sandwich Generation. Rising Financial Burdens for Middle-Aged Americans. Social\&Demographic Trends, PewResearch Centre, Retrieved from http://www.pewsocialtrends.org/files/2013/01/Sandwich_Generation_Report_F INAL_1-29.pdf

Warner, M., Homsy, G., \& Greenhouse, E. (2010). Multi-generational community planning: Linking the needs of children and older adults. Department of City and Regional Planning, Cornell University, Retrieved form http://s3.amazonaws.com/mildredwarner.org/attachm ents/000/000/176/original /cffc72d40accc1b0c7edb5812586eacb

Zruz-Saco, M.A., \& Zelenev, S. (2010). Intergenerational solidarity. Strengthening economic and social ties. New York: Palgrave Macmillan.

Żołędowski, C. (2012). Starzenie się ludności - Polska na tle Unii Europejskiej. Problemy polityki społecznej. Studia i dyskusje, 17. 